\title{
Industry-Specific Scale: A review on Job Satisfaction of Offshore Employees
}

Mohd Aliff Abdul Majid, Hairul Nizwan Abd Majid \& Muhammad Afnan Mahusain

To Link this Article: http://dx.doi.org/10.6007/IJARBSS/v11-i2/9195

DOI:10.6007/IJARBSS/v11-i2/9195

Received: 08 December 2020, Revised: 12 January 2021, Accepted: 26 January 2021

Published Online: 19 February 2021

In-Text Citation: (Majid et al., 2021)

To Cite this Article: Majid, M. A. A., Majid, H. N. A., \& Mahusain, M. A. (2021). Industry-Specific Scale: A review on Job Satisfaction of Offshore Employees. International Journal of Academic Research in Business and Social Sciences Journal, 11(2), 995-1005.

Copyright: (c) 2021 The Author(s)

Published by Human Resource Management Academic Research Society (www.hrmars.com)

This article is published under the Creative Commons Attribution (CC BY 4.0) license. Anyone may reproduce, distribute, translate and create derivative works of this article (for both commercial and non-commercial purposes), subject to full attribution to the original publication and authors. The full terms of this license may be seen at: http://creativecommons.org/licences/by/4.0/legalcode

Vol. 11, No. 2, 2021, Pg. 995 - 1005

Full Terms \& Conditions of access and use can be found at http://hrmars.com/index.php/pages/detail/publication-ethics 


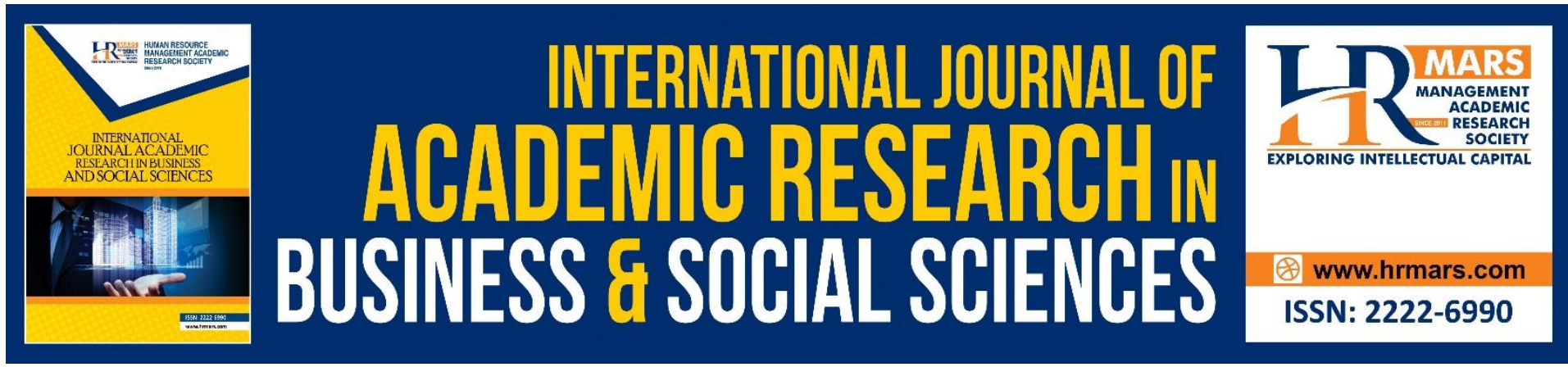

\title{
Industry-Specific Scale: A review on Job Satisfaction of Offshore Employees
}

\author{
Mohd Aliff Abdul Majid ${ }^{a}$, Hairul Nizwan Abd Majid ${ }^{a}$ \& \\ Muhammad Afnan Mahusain ${ }^{b}$
}

aFaculty of Hotel and Tourism Management, Universiti Teknologi MARA Puncak Alam, Selangor, Malaysia, 'School of Hospitality and Tourism, Taylor's University, Subang Jaya,

Selangor, Malaysia

\begin{abstract}
The research of job satisfaction has become significant to any business and is a common issue in the area of unusual work environments such as the military, offshore, maritime, polar exploration, nuclear power plants and space programs. Although research in offshore has received much attention, studies on job satisfaction within the context is still limited. Moreover, none of these studies provided structural evidence of a job satisfaction instrument that specifically measures job satisfaction among offshore employees. In fact, these studies used existing instruments to measure employees' job satisfaction in the offshore context. The absence of a suitable scale to assess employees' attitudes on job satisfaction might not capture the employees' real feelings about their satisfaction with the job. Therefore, there is a need for an industry-specific scale measuring offshore employee's job satisfaction.
\end{abstract}

Keywords: Industry-Specific, Instrument, Job Satisfaction, Offshore, Scale.

\section{Introduction}

\section{Research Background}

In today's competitive era, the primary source in gaining competitive advantage and organizational performance is determined by how employees are treated (Todorović, Čabarkapa, Tošić-Radev \& Miladinović, 2017; Kandasamy \& Ancheri, 2009; Lawler 2005). No organization would be able to achieve its organizational goals or financial aim without its employees (Johari, Yahya \& Ahmad, 2012). Tews, Michel and Bartlett (2012) mentioned that hiring competent employees is an elementary phase to ensure a productive workforce and effective organizational performance.

Previous literature demonstrated that reduced job satisfaction was significantly related to employee turnover (Scanlan \& Still, 2013; Shen \& Zhu, 2012; Tett \& Meyer, 1993; Carsten \& Spector, 1987), poor organizational commitment (Kim, Leong \& Lee, 2005; Meyer \& Smith, 2001) and low job performance (Patterson, Warr \& West, 2004; Judge, Thoresen, Bono \& Patton, 2001). On the contrary, job satisfaction leads to higher employee commitment, reduced employee turnover and improved organizational performance. This implies that job satisfaction plays an important role in determining the success of an organization and 
research on job satisfaction has gain extensive attention among scholars and practitioners in many work contexts.

Despite of studies in hypothetical organizations, research in unusual and challenging environment has become a central concern to a substantial number of psychology scholars (Sandal, Leon \& Palinkas, 2006). However, very little is known regarding the actual behavior of people working in unusual environments (Zimmer et al., 2013; Suedfeld, 1998). Kanas (1997) asserted that the study of isolated and confined extreme (ICE) environments is of major interest to understand the concept of adaptation. Sandal et al. (2006) mentioned that these environments have a significant influence on behavioral functioning. The aforementioned environments share similar characteristics of working far from home, being exposed to dangerous conditions and social isolation, working in a narrow working space, facing high workload and experiencing communication constraints with the outside world (Tafforin, 2002; Lugg \& Shepanek, 1999; Wood, Lugg, Hysong \& Harm, 1999; Sutherland \& Flin, 1989). Examples of unusual work environments such as the military (Chin-Siang, Talib, Juhari \& Madon, 2014; Bokti \& Talib, 2009), offshore (Majid, Othman, Mohamad \& Lim, 2017; Harun, Salleh, Memon, Baharom \& Abdullah, 2014; Dickey, Watson \& Zangelidis, 2011; Ulleberg \& Rundmo, 1997), maritime (Bergheim, Nielsen, Mearns \& Eid 2015; Nielsen, Eid, Hystad, Sætrevik \& Saus, 2013, Nielsen, Mearns, Matthiesen \& Eid, 2011), polar exploration (Sarris, 2008), nuclear power plants (Gracia \& Martínez-Córcoles, 2018) and space programs (Kanas et al., 2000). Despite of many potential areas of ICE work environments to be studied, this research particularly focused on offshore context.

The offshore working group presents a unique situation that needs to be explicitly addressed compared to the onshore working environment (Afzainizam, Embong, Yaacob, Sabina, Ashgaftaki \& Elsayed, 2016; Ross, 2009). Hence, maintaining employees' satisfaction in the offshore context is challenging. It illustrates that the industry is described as 'high risk', where they face a challenging work environment. Moreover, Elliot (1985) described the offshore working environment as difficult, dangerous and socially isolated. Besides that, the offshore working environment exposes its workers to high rates of hazards, calamity and accidents (Bergheim et al., 2015).

The employees are transported and stay on the vessel for a minimum of 14 days. As a result of this opportunity, attention should be paid to the outcomes of working in this challenging working environment. Yuen, Loh, Zhou and Wong (2018) asserted that job satisfaction plays a vital role in retaining these employees. However, the main areas of studies on offshore employees have been primarily related to risk management issues, health, safety, and environment (HSE), and job stress (Harun et al., 2014; Rundmo, 1992). This notion holds true especially for offshore, where only slight attention has been devoted on job satisfaction. Therefore, there is a need for researchers to investigate their job satisfaction using industryspecific scale in order to capture their true evaluation working at offshore. The main purpose of the article is to review the issue in measurement tools and identify research gap in developing an offshore-specific scale measuring job satisfaction.

\section{Research Problem}

The number of employees working in the offshore industry continues to drop, and younger employees feel less attracted to work in this industry as most of them prefer onshore jobs (Li, 
Yin, Luo \& Wang, 2014). The shortage and low retention rates had placed a burden on recruitment and increased the associated costs (Li et al., 2014). Furthermore, offshore jobs are considered as high risk industry; thus, onshore jobs are perceived to provide better job opportunities. The notion holds true as Dickey et al. (2011) purported that the willingness of people to accept offshore jobs is dependent on the nature and quantity of onshore jobs. It is said that, offshore job will be accepted as a substitute career when they are unable to fill the job at onshore.

Measuring employee's job satisfaction is complex as offshore jobs are different from onshore jobs. Various scales were developed in different work contexts, primarily concerning manufacturing workers. Fields (2002) reviewed 23 validated job satisfaction scales that have been employed in various industries; however, none of the scales were purposely developed for the offshore context. The existing scales (e.g., Job Descriptive Index, Job Satisfaction Survey and Job Diagnostic Survey) were mainly developed in management and professional sectors. There is a concern that the existing scales could be cultural and job-dependent. Applying them to other nationalities or companies other than those originally intended to be measured might pose weighty limitations. The absence of a suitable scale to assess employees' attitudes on job satisfaction might not capture the employees' real feelings about their satisfaction with the job. Hence, the literature has mirrored the need of an industryspecific scale measuring offshore employee's job satisfaction. This new scale can assist job satisfaction scholars and practitioners to understand the perception of the employees pertaining to their job satisfaction in general.

\section{Literature Review \\ Job Satisfaction Scales}

There are a variety of scales measuring job satisfaction in organizational research. Few studies (e.g., Mahdi, Zin, Nor, Sakat \& Naim, 2012; Stanton, Sinar, Balzer, Julian, Thoreson, Aziz, Fisher \& Smith, 2001) claimed that the Job Descriptive Index (JDI) developed by Smith, Kendall and Hulin (1969) is the most researched scale of job satisfaction. Other researchers (e.g., Giri \& Kumar, 2010; Yelboga, 2009; Liu, Borg \& Spector 2004) contended that the Job Satisfaction Survey (JSS) developed by Spector (1985) is the most extensively employed scale for measuring job satisfaction. Nevertheless, following several retests, it was found that the existing scales could not be generalized to every work setting as anticipated without proper adjustments to its attributes (Heritage, Pollock \& Roberts, 2015; Chin-Siang et al., 2014; Astrauskaite, Vaitkevičius \& Perminas 2011).

In the sense, many researchers have developed more industry-specific scales of job satisfaction. For example, Özpehlivan and Acar (2015) developed a job satisfaction scale for textile employees; Pollnac, Seara and Colburn (2015) and Pollnac and Poggie (1988) for commercial fishermen; Astrauskaite et al. (2011) for secondary school teachers; Lee, Magnini and Kim (2011) for South Korean hotel frontline employees; Sowmya and Panchanatham (2011) for Indian banking employees; Judge, Boudreau and Bretz (1994) for male executives; Rothausen (1994) for retail employees; Shouksmith (1989) for New Zealand veterinarians; and Mueller and McCloskey (1990) for nurses.

It is anticipated that little empirical effort has been conducted to develop an offshore-based scale. Moreover, little is known pertaining to the contextual settings in terms of the 
associations and dimensions that contribute to the employee's job satisfaction. A bespoke scale could provide substantial evidence to organizations to signify the existence of job satisfaction and dissatisfaction as well as the specific attributes of job satisfaction that are most lacking.

\section{Previous Studies on Job Satisfaction}

There have been a considerable number of studies on job satisfaction using questionnaires (Sutherland \& Cooper, 1989; Sutherland \& Flin, 1989; Rundmo, 1996; Ulleberg \& Rundmo, 1997; Wickramasinghe, 2009; Wickramasinghe \& Jayaweera, 2010; Dickey et al., 2011; Nielsen et al., 2011; Nielsen et al., 2013; Harun et al., 2014; Li et al., 2014; Olaniyan \& Hystad, 2016; Yuen et al., 2018). However, none of these studies provided structural evidence of a job satisfaction scale that specifically measures job satisfaction among offshore employees. Moreover, these studies used existing scales to measure employees' job satisfaction in the offshore context. The following table presents the job satisfaction scales that were used in previous offshore studies and the findings of the particular studies.

Table 1: Job satisfaction scale used in previous offshore studies

\begin{tabular}{|c|c|c|c|}
\hline Author & $\begin{array}{c}\text { Source of } \\
\text { scale }\end{array}$ & $\begin{array}{c}\text { Area of } \\
\text { research }\end{array}$ & Findings \\
\hline $\begin{array}{l}\text { Sutherlan } \\
\text { d \& Flin } \\
\text { (1989) }\end{array}$ & $\begin{array}{l}\text { Warr, Cook } \\
\& \text { Wall } \\
(1979)\end{array}$ & $\begin{array}{l}\text { UK } \\
\text { Continenta } \\
\text { I Shelf } \\
\text { (UKCS) }\end{array}$ & $\begin{array}{l}\text { This study examined some of the psychological and } \\
\text { social aspects of offshore working life. The study } \\
\text { findings demonstrated that individuals reporting } \\
\text { higher levels of stress on offshore stress showed } \\
\text { lower levels of job satisfaction and mental } \\
\text { wellbeing. The results also revealed that rate of pay } \\
\text { had the lowest score, while fellow workers obtained } \\
\text { the highest score among the contractors. }\end{array}$ \\
\hline $\begin{array}{l}\text { Sutherlan } \\
\text { d \& } \\
\text { Cooper } \\
\text { (1989) }\end{array}$ & $\begin{array}{l}\text { Warr et al. } \\
\text { (1979) }\end{array}$ & $\begin{array}{l}\text { European } \\
\text { waters }\end{array}$ & $\begin{array}{l}\text { The study established that no significant differences } \\
\text { that reported stress levels or stress manifestations } \\
\text { (i.e., job satisfaction. mental health, alcohol or } \\
\text { tobacco usage) were observed between introverts } \\
\text { and extraverts. }\end{array}$ \\
\hline $\begin{array}{l}\text { Rundmo } \\
\text { (1996) }\end{array}$ & $\begin{array}{l}\text { Adopted } \\
\text { from } \\
\text { Rundmo \& } \\
\text { Saari (1988) } \\
\end{array}$ & $\begin{array}{l}\text { Norwegian } \\
\text { part of the } \\
\text { North Sea }\end{array}$ & $\begin{array}{l}\text { The study found a greater percentage of employees } \\
\text { were satisfied with safety and contingency } \\
\text { measures, and experienced job stress. }\end{array}$ \\
\hline $\begin{array}{l}\text { Ulleberg \& } \\
\text { Rundmo } \\
\text { (1997) }\end{array}$ & $\begin{array}{l}\text { Warr et al. } \\
(1979)\end{array}$ & $\begin{array}{l}\text { Norwegian } \\
\text { part of the } \\
\text { North Sea }\end{array}$ & $\begin{array}{l}\text { The results showed that the respondents felt least } \\
\text { satisfied with the dimension on employee relations, } \\
\text { and especially with regards to promotion prospects. } \\
\text { In general, the results suggested that the } \\
\text { respondents felt satisfied with their jobs. }\end{array}$ \\
\hline $\begin{array}{l}\text { Wickrama } \\
\text { singhe } \\
(2009)\end{array}$ & $\begin{array}{l}\text { Adapted } \\
\text { from } \\
\text { previous } \\
\text { studies in } \\
\text { management } \\
\text { information } \\
\end{array}$ & $\begin{array}{l}\text { Sri Lanka's } \\
\text { offshore } \\
\text { outsourcin } \\
\text { g sector }\end{array}$ & $\begin{array}{l}\text { The results indicated that gender and tenure were } \\
\text { significant in job satisfaction measurement. } \\
\text { Females were less satisfied with their jobs and felt } \\
\text { a loss of interest in jobs but wish to remain in their } \\
\text { present workplace. Those with a longer tenure in } \\
\text { their present workplace were less satisfied with }\end{array}$ \\
\hline
\end{tabular}




\begin{tabular}{|c|c|c|c|}
\hline & & & $\begin{array}{l}\text { their jobs, felt a loss of interest in their jobs and } \\
\text { intended to leave their present workplace. }\end{array}$ \\
\hline $\begin{array}{l}\text { Wickrama } \\
\text { singhe \& } \\
\text { Jayaweera } \\
\text { (2010) }\end{array}$ & $\begin{array}{l}\text { Rusbult \& } \\
\text { Farrell (1983) }\end{array}$ & $\begin{array}{l}\text { Sri Lanka's } \\
\text { offshore } \\
\text { outsourcin } \\
\text { g sector }\end{array}$ & $\begin{array}{l}\text { The study was to examine the mediating effect of } \\
\text { job satisfaction on the relationship between time } \\
\text { demands of work and turnover intention. It was } \\
\text { found that job satisfaction partially mediated the } \\
\text { relationship between time demands of work and } \\
\text { turnover intention. }\end{array}$ \\
\hline $\begin{array}{l}\text { Dickey et } \\
\text { al. (2011) }\end{array}$ & $\begin{array}{l}\text { Adapted } \\
\text { from } \\
\text { previous job } \\
\text { satisfaction, } \\
\text { psychology } \\
\text { and } \\
\text { occupational } \\
\text { health } \\
\text { research }\end{array}$ & $\begin{array}{l}\text { UK } \\
\text { Sea }\end{array}$ & $\begin{array}{l}\text { The study investigated the determinants of job } \\
\text { satisfaction and intentions to quit. They found that } \\
\text { for those in good financial situations, skills were } \\
\text { closely related to their job and those who received } \\
\text { training reported higher levels of job satisfaction. } \\
\text { Moreover, the study established the importance of } \\
\text { job satisfaction in determining workers' intentions } \\
\text { to quit their job. }\end{array}$ \\
\hline $\begin{array}{l}\text { Nielsen et } \\
\text { al. (2011) }\end{array}$ & $\begin{array}{l}\text { Overall Job } \\
\text { Satisfaction } \\
\text { (Brayfield \& } \\
\text { Rothe, 1951) }\end{array}$ & $\begin{array}{l}\text { Norwegian } \\
\text { offshore }\end{array}$ & $\begin{array}{l}\text { The study hypothesized that high levels of risk } \\
\text { perception were related to low job satisfaction and } \\
\text { that a positive perception of safety climate was } \\
\text { related to high job satisfaction. It was found that } \\
\text { workers who perceived high levels of risk reported } \\
\text { lower levels of job satisfaction }\end{array}$ \\
\hline $\begin{array}{l}\text { Nielsen et } \\
\text { al. (2013) }\end{array}$ & $\begin{array}{l}\text { Overall Job } \\
\text { Satisfaction } \\
\text { (Brayfield \& } \\
\text { Rothe, 1951) }\end{array}$ & $\begin{array}{l}\text { Norwegian } \\
\text { offshore }\end{array}$ & $\begin{array}{l}\text { The study was to report psychometric properties of } \\
\text { safety climate inventory. Moderate to strong } \\
\text { positive correlations were established between } \\
\text { safety climate dimensions and job satisfaction. } \\
\text { Moreover, employees who perceived the safety } \\
\text { climate as strong reported more job satisfaction } \\
\text { than those who perceived the safety climate as less } \\
\text { positive. }\end{array}$ \\
\hline $\begin{array}{l}\text { Harun et } \\
\text { al. (2014) }\end{array}$ & $\begin{array}{l}\text { Job } \\
\text { Satisfaction } \\
\text { Survey } \\
\text { (Spector, } \\
\text { 1997) }\end{array}$ & $\begin{array}{l}\text { Coast of } \\
\text { East } \\
\text { Malaysia }\end{array}$ & $\begin{array}{l}\text { The findings showed a moderate level of stress and } \\
\text { job satisfaction, while organizational commitment } \\
\text { was found to be quite high among the sample. Job } \\
\text { satisfaction was found to have significant positive } \\
\text { association with organizational commitment and } \\
\text { stress was found to be negatively correlated to } \\
\text { organizational commitment and job satisfaction. }\end{array}$ \\
\hline $\begin{array}{l}\text { Li et al. } \\
\text { (2014) }\end{array}$ & $\begin{array}{l}\text { Adapted } \\
\text { from } \\
\text { previous } \\
\text { studies }\end{array}$ & $\begin{array}{l}\text { Chinese } \\
\text { offshore }\end{array}$ & $\begin{array}{l}\text { The study was to investigate the main factors that } \\
\text { contributed to job satisfaction of Chinese seafarers. } \\
\text { It was found that promotion was the most } \\
\text { significant factor in job satisfaction, followed by } \\
\text { salary and benefits, working environment and } \\
\text { feeling of status. }\end{array}$ \\
\hline $\begin{array}{l}\text { Olaniyan } \\
\text { \& Hystad } \\
(2016) \\
\end{array}$ & $\begin{array}{l}\text { Overall Job } \\
\text { Satisfaction }\end{array}$ & $\begin{array}{l}\text { North Sea } \\
\text { and }\end{array}$ & $\begin{array}{l}\text { Findings showed that employees who perceived } \\
\text { their leader as being authentic reported more job }\end{array}$ \\
\hline
\end{tabular}




\begin{tabular}{|c|c|c|c|}
\hline & $\begin{array}{l}\text { (Brayfield \& } \\
\text { Rothe, 1951) }\end{array}$ & $\begin{array}{l}\text { Southeast } \\
\text { Asia }\end{array}$ & $\begin{array}{l}\text { satisfaction and less job insecurity and intentions to } \\
\text { quit the organization. }\end{array}$ \\
\hline $\begin{array}{l}\text { Yuen et al. } \\
\text { (2018) }\end{array}$ & $\begin{array}{l}\text { Wanous, } \\
\text { Reichers \& } \\
\text { Hudy (1997) }\end{array}$ & $\begin{array}{l}\text { Singaporea } \\
\mathrm{n} \quad \text { ship } \\
\text { manageme } \\
\mathrm{nt} \\
\text { companies }\end{array}$ & $\begin{array}{l}\text { The objective of the study was to analyze the core } \\
\text { determinants of job satisfaction and performance } \\
\text { of seafarers. The results show that job satisfaction } \\
\text { was considerably correlated with job performance } \\
\text { of seafarers. }\end{array}$ \\
\hline
\end{tabular}

The table reports previous studies conducted in the offshore context using existing instruments rather than developing it for specific purposes. In fact, to date, little effort has been made to produce an industry-specific scale within the offshore work environment, indicating that previous researchers modified existing scales to suit the context of the study. Closely related to the research issue is the work of Dickey et al. (2011) that measured the job satisfaction of offshore workers in the oil and gas industry. The work largely followed Ulleberg and Rundmo's (1997) study. However, the scale used by Ulleberg and Rundmo (1997) to measure their samples was adapted from Warr et al. (1979). Looking at the work of Warr et al. (1979), the scale was initially developed for manufacturing workers within the mainland of United Kingdom. This leaves questions on the accuracy of the items measuring the samples from different industries. Underestimating the effects of job, cultural, social and location characteristics may offer inaccurate responses. It is contended that the selection of job satisfaction factors among manufacturing workers will not equally contain a similar selection of factors among offshore workers. More importantly, research on job satisfaction conducted in the offshore context are growing; hence, it is probably important to claim that a specificindustry scale is needed to measure the phenomenon to provide better, accurate and meaningful information.

\section{Conclusion and Recommendation}

In light of the above discussion, scholars could use previous developed scales, depending on the intended objectives of the study. However, the use of existing scales to measure different samples should be applied with caution. It is important to consider whether the previous samples used to develop the scale have similar characteristics to the samples in the proposed study. There is a reason to be concerned that might affect the way that respondents interpret the statements in the scale. As the needs and perception of employee working in offshore environment are complex and diverse, the need of offshore-based scale is necessary to obtain meaningful information. The data obtained would be helpful to scholars and practitioners to make necessary actions.

\section{Corresponding Author}

Mohd Aliff Abdul Majid

Department of Foodservice Management, Faculty of Hotel and Tourism Management, Universiti Teknologi MARA Puncak Alam, Selangor, Malaysia

Email: mhaliff@uitm.edu.my

\section{References}

Afzainizam, N., Embong, A. M., Yaacob, R. A. I. R., Sabina, N. A. A., Ashgaftaki, A. A., \& Elsayed, M. M. (2016). Job stress among offshore personnel in oil and gas extraction industries. Indian Journal of Science and Technology, 9(9), 1-6. 
Astrauskaite, M., Vaitkevičius, R., \& Perminas, A. (2011). Job Satisfaction Survey: A confirmatory factor analysis based on secondary school teachers' sample. International Journal of Business and Management, 6(5), 41-50.

Bergheim, K., Nielsen, M. B., Mearns, K., \& Eid, J. (2015). The relationship between psychological capital, job satisfaction, and safety perceptions in the maritime industry. Safety Science, 74, 27-36.

Bokti, N. L. M., \& Talib, M. A. (2009). A preliminary study on occupational stress and job satisfaction among male navy personnel at a naval base in Lumut, Malaysia. The Journal of International Social Research, 2(9), 299-307.

Brayfield, A. H., \& Rothe, H. F. (1951). An index of job satisfaction. Journal of Applied Psychology, 35, 307-311.

Carsten, J. M., \& Spector, P. E. (1987). Unemployment, job satisfaction and employee turnover: A meta-analytic test of the Muchinsky model. Journal of Applied Psychology, $72,199-212$.

Chin-Siang, A., Talib, M. A., Juhari, R., \& Madon, Z. (2014). Psychometric properties of the Malay version of the job satisfaction survey among Malaysian military personnel. Pertanika Journal of Social Science \& Humanities, 22(1), 285-306.

Dickey, H., Watson, V., \& Zangelidis, A. (2011). Job satisfaction and quit intentions of offshore workers in the UK North Sea oil and gas industry. Scottish Journal of Political Economy, 58(5) 607-633.

Elliot, D. H. (1985). The offshore worker. The Practitioner, 229, 565-571.

Fields, D. (2002). Taking Measure of Work: A Guide to Validated Scales for Organizational Research and Diagnosis. Thousand Oaks, CA: Sage Publications.

Giri, V. N., \& Kumar, B. P. (2010). Assessing the impact of organizational communication on job satisfaction and job performance. Psychological Studies, 55(2), 137-143.

Gracia, F. J., \& Martínez-Córcoles, M. (2018). Understanding risky behaviours in nuclear facilities: The impact of role stressors. Safety Science, 104, 135-143.

Harun, H., Salleh, R., Memon, M. A., Baharom, M. N. R., \& Abdullah, A. (2014). Job satisfaction, organizational commitment and stress among offshore oil and gas platform employees. Asian Social Science, 10(11), 28-32.

Heritage, B., Pollock, C., \& Roberts, L. D. (2015). Confirmatory factor analysis of Warr, Cook, and Wall's (1979) Job Satisfaction Scale. Australian Psychologist, 50, 122-129.

Johari, J., Yahya, K. K., \& Ahmad, M. N. (March 2012). Understanding the influence of human resource management practices on intention to stay: Evidence from Malaysia. Paper presented at the 3rd International Conference on Economic and Business Research Proceeding, Bandung, Indonesia.

Judge, T. A., Boudreau, J. W., \& Bretz, R. D., Jr. (1994). Job and life attitudes of male executives. Journal of Applied Psychology, 79(5), 767-782.

Judge, T. A., Thoresen, C. J., Bono, J. E., \& Patton, G. K. (2001). The job satisfaction-job performance relationship: A qualitative and quantitative review. Psychological Bulletin, $127,376-407$.

Kanas, N., Salnitskiy, V., Grund, E. M., Gushin, V., Weiss, D. S., Kozerenko, O., ... \& Marmar, C. R. (2000). Social and cultural issues during Shuttle/Mir space missions. Acta Astronautica, 47(2-9), 647-655.

Kandasamy, I., \& Ancheri, S. (2009). WRKLFQUAL: A tool for measuring quality of work life. Research and Practice in Human Resource Management, 17(1), 59-70. 
Kim, W. G., Leong, J. K. and Lee, Y. K. (2005). Effect of service orientation on job satisfaction, organizational commitment, and intention of leaving in a casual dining chain restaurant. Hospitality Management, 24(2), 171-193.

Lee, G., Magnini, V. P., \& Kim, B. P. (2011). Employee satisfaction with schedule flexibility: Psychological antecedents and consequences within the workplace. International Journal of Hospitality Management, 30(1), 22-30.

Li, K. X., Yin, J., Luo, M., \& Wang, J. (2014). Leading factors in job satisfaction of Chinese seafarers. International Journal of Shipping and Transport Logistics, 6(6), 680-693.

Liu, C., Borg, I., \& Spector, P. E. (2004). Measurement invariance of the German job satisfaction survey used in a multinational organization: Implications of Schwartz's culture model. Journal of Applied Psychology, 89(6), 1070-1082.

Lugg, D., \& Shepanek, M. (1999). Space analogue studies in Antarctica. Acta Astronautica, 44(7), 693-699.

Mahdi, A. F., Zin, M. Z. M., Nor, M. R. M., Sakat, A. A., \& Naim, A. S. A. (2012). The relationship between job satisfaction and turnover intention. American Journal of Applied Sciences, 9(9), 1518-1526.

Meyer, J. P., \& Smith, C. A. (2001). HRM practices and organizational commitment: Test of a mediation model. Canadian Journal of Administrative Sciences, 17(4), 319-331.

Mueller, C. W., \& McCloskey, J. C. (1990). Nurses' job satisfaction: A proposed measure. Nursing Research, 39, 113-117.

Nielsen, M. B., Eid, J., Hystad, S. G., Sætrevik, B., \& Saus, E. R. (2013). A brief safety climate inventory for petro-maritime organizations. Safety Science, 58, 81-88.

Nielsen, M. B., Mearns, K., Matthiesen, S. B., \& Eid, J. (2011). Using the Job DemandsResources model to investigate risk perception, safety climate and job satisfaction in safety critical organizations. Scandinavian Journal of Psychology, 52(5), 465-475.

Olaniyan, O. S., \& Hystad, S. W. (2016). Employees' psychological capital, job satisfaction, insecurity, and intentions to quit: The direct and indirect effects of authentic leadership. Journal of Work and Organizational Psychology, 32(3), 163-171.

Özpehlivan, M., \& Acar, A. Z. (2015). Assessment of a multidimensional job satisfaction instrument. Procedia - Social and Behavioral Sciences, 210, 283-290.

Pollnac, R. B., Seara, T., \& Colburn, L. L. (2015). Aspects of fishery management, job satisfaction, and well-being among commercial fishermen in the Northeast Region of the United States. Society \& Natural Resources, 28(1), 75-92.

Pollnac, R. B., \& Poggie, J. J. (1988). The structure of job satisfaction among New England fishermen and its application to fisheries management policy. American Anthropologist, 90(4), 888-901.

Patterson, M., Warr, P., \& West, M. (2004). Organizational climate and company productivity: The role of employee affect and employee level. Journal of Occupational and Organizational Psychology, 77, 193-216.

Ross, J. K. (2009). Offshore industry shift work - health and social considerations. Occupational Medicine, 59, 310-315.

Rothausen, T. J. (1994). Job satisfaction and the parent worker: The role of flexibility and rewards. Journal of Vocational Behavior, 44, 317-336.

Rundmo, T. (1996). Changes in risk perception among North Sea offshore personnel in the period 1990 to 1994. Safety Science, 21(3), 205-221.

Rundmo, T. (1992). Risk perception and safety on offshore petroleum platforms. 2. Perceived risk, job stress and accidents. Safety Science, 15(1), 53-68. 
Rundmo, T., \& Saari, J. (1988). Safety program factors. In Safe Behaviour-Accident Prevention Measures. Tampere University of Technology, Department of Mechanical Engineering Tampere.

Rusbult, C. E. \& Farrell, D. (1983). A longitudinal test of the investment model: the impact of job satisfaction, job commitment, and turnover of variations in rewards, costs, alternatives, and investments. Journal of Applied Psychology, 68(3), 429-438.

Sandal, G. M., Leon, G. R., \& Palinkas, L. (2006). Human challenges in polar and space environments. Reviews in Environmental Science and Biotechnology, 5, 281-296.

Scanlan, J. N., \& Still, M. (2013). Job satisfaction, burnout and turnover intention in occupational therapists working in mental health. Australian Occupational Therapy Journal, 60, 310-318.

Shen, W. Y., \& Zhu, J. W. (2012). Enterprise job satisfaction and turnover intention. Social Scientist, 12, 80-83.

Shouksmith, G. (1989). A construct validation of a scale for measuring work motivation. New Zealand Journal of Psychology, 18, 76-81.

Smith, P. C., Kendall, L. M., \& Hulin, C. L. (1969). The measurement of satisfaction in work and retirement. Chicago: Rand McNally.

Sowmya, K. R., \& Panchanatham, N. (2011). Factors influencing job satisfaction of banking sector employees in Chennai, India. Journal of Law and Conflict Resolution, 3(5), 76-79.

Spector, P. E. (1997). Job satisfaction: Application, assessment, causes, and consequences. London: Thousand Oaks, CA: Sage Publications.

Spector, P. E. (1985). Measurement of human service staff satisfaction: Development of the job satisfaction survey. American Journal of Community Psychology, 13(6), 693-713.

Stanton, J. M., Sinar, E. F., Balzer, W. K., Julian, A. L., Thoreson, P., Aziz, S., Fisher, G. G., \& Smith, P. C. (2001). Development of a compact measure of job satisfaction: the abridged job descriptive index. Educational and Psychological Measurement, 61(6), 1104-1122.

Suedfeld, P. (1998). What can abnormal environments tell us about normal people? Polar stations as natural psychology laboratories. Journal of Environmental Psychology, 18, 95-102.

Sutherland, V. J., \& Cooper, C. L. (1989). Occupational stress in the offshore oil and gas industry. International Reviews of Ergonomics 3, 183-215.

Sutherland, K. M., \& Flin, R. H. (1989) Stress at sea: A review of working conditions in the offshore oil and fishing industries. Work \& Stress: An International Journal of Work, Health \& Organisations, 3(3), 269-285.

Tafforin, C. (2002). Ethological observations on a small group of wintering members at dumont d'urville station (terre Adeilie). Antarctic Science, 14(4), 310-318.

Tett, R. P., \& Meyer, J. P. (1993). Job satisfaction, organizational commitment, turnover intention: Path analyses on meta-analytic findings. Personnel Psychology, 46, 259-293.

Tews, M. J., Michel, J. W., \& Bartlett, A. (2012). The fundamental role of workplace fun in applicant attraction. Journal of Leadership and Organizational Studies, 19(1), 105-114.

Todorović, D., Čabarkapa, M., Tošić-Radev, M., \& Miladinović, I. (2017). Organizational identification, commitment and orientations of professional military personnel. Vojnosanitetski Pregled, 74(9), 871-877.

Ulleberg, P., \& Rundmo, T. (1997). Job stress, social support, job satisfaction and absenteeism among offshore oil personnel. Work \& Stress, 11(3), 215-228.

Wanous, J. P., Reichers, A. E., \& Hudy, M. J. (1997). Overall job satisfaction: How good are single-item measures?. Journal of Applied Psychology, 82(2), 247. 
Warr, P., Cook, J., \& Wall, T. (1979). Scales for the measurement of some work attitudes and aspects of psychological well-being. Journal of Occupational Psychology, 52, 129- 148.

Wickramasinghe, V., \& Jayaweera, M. (2010). Impact of career plateau and supervisory support on career satisfaction: A study in offshore outsourced IT firms in Sri Lanka. Career Development International, 15(6), 544-561.

Wickramasinghe, V. (2009). Predictors of job satisfaction among IT graduates in offshore outsourced IT firms. Personnel Review, 38(4), 413-431.

Wood, J., Lugg, D. J., Hysong, S. J., \& Harm, D. L. (1999). Psychological changes in hundred-day remote Antarctic field groups. Environment and Behavior, 31(3), 299-337.

Yelboga, A. (2009). Validity and reliability of the Turkish version of the job satisfaction survey (JSS). World Applied Sciences Journal, 6(8), 1066-1072.

Yuen, K. F., Loh, H. S., Zhou, Q., \& Wong, Y. D. (2018). Determinants of job satisfaction and performance of seafarers. Transportation Research Part A: Policy and Practice, 110, 112.

Zimmer, M., Cabral, J. C. C. R., Borges, F. C., Côco, K. G., \& Hameister, B. D. R. (2013). Psychological changes arising from an Antarctic stay: Systematic overview. Estudos de Psicologia (Campinas), 30(3), 415-423. 